\title{
sciendo
}

DOI: $10.2478 /$ rjp-2019-0021

Rom J Psychoanal 2019, 12(2):131-139

Rom J Psychoanal

\section{THE TOTALITARIAN CREATION IN ITS CLAIM OF GENIUS}

Zinaida Bolea ${ }^{10}$

\begin{abstract}
Creation is a fundamental definition of genius, and we are wondering if those minds that created totalitarian systems, could remain in human history through destructive impact on millions of people's minds, and could they possibly be included in genius category. Certainly, we could support the idea of the participation of these people in the creation process - in the creation of ideology of a new world, of a new Human etc. At the same time, the Real Human is perceived only as an object that can be manipulated, overwhelmed, dominated, controlled, destroyed etc., "love" and "investment" of the evil genius being dedicated to a non-existent Ideal Human. We are trying to understand what are the pillars of the relationship with the Others, and the dictators' great seduction capacity. In the condition of the incapacity and inability of these personalities to appreciate humanity, most of them were able to provoke admiration. In the context of these paradoxical relations, becomes noticeable the responsibility of understanding the way perverse mind speaks with our minds in a way that we became available consciously or unconsciously to join in this destructive creation.
\end{abstract}

Key words: creativity, genius, totalitarian system, narcissistic perversion, ambivalence, manipulation, schizo-paranoid position, depressive position, perverse thought.

\footnotetext{
${ }^{10}$ Romanian Society of Psychoanalysis,zbolea@yahoo.com
} 


\section{Introduction}

Being involved in a research project dedicated to deportations from the Moldavian SSR in the years 1940-1941 and 1944-1953, colleagues often asked me about the specifics of the dictator's personality and the phenomenon of mass following to the dictatorial ideology. In general terms, through reflection in this text, I will refer to the dictators of the XXth century in the European space - Hitler, Stalin, and Ceausescu - but as an example I will take Hitler's personality, as described by Eric Fromm in his work "The Anatomy of Human Destructiveness" (1973). In my summary presentation I was wondering if contemporaneous dictators could pretend being involved in the creation process. At the time of writing this summary, I was referring to the perverse-narcissistic creation that I considered being the closest to totalitarian systems and which has a central feature in manipulating and abolishing the Other. At the same time, a dictator cannot exist without the mass, perverse thought is always linked to our psyche and we are often available, consciously or unconsciously, to join this destructive creation. In this sense, Hannah Arendt (1964/2018, p. 22) mentions how XXth Century dictatorial figures were idealized not only by ordinary people, but also by intellectuals: "You see, if someone obeys an ideologist because he had to protect his wife and child, no one would blame him. The horror appeared when they started to believe in this situation! ... But it still meant that the ideas were made about Hitler. And sometimes there were some awfully interesting ideas!”.

To give a brief introduction to what means Creation, I will begin with Didier Anzieu's The Body of the work. Psychoanalytical essays on creative work (1981). Anzieu argues that psychoanalysts have always been interested in capturing the processes of transformation operations: as transformations that ensure the transition from mental health to mental disorders, the transition from mental disorders to sanity, the transition from creativity to creation - all these transformations are resulted from psychic work. Anzieu describes three forms of mental work: dream work, mourning work, and creation work and considers that dream, mourning, and creativity share common features to create crisis phases for the psyche. From the author's point of view, a mental crisis includes "internal turmoil, an exacerbation of an individual's pathology, an interrogation of acquired structures, internal and external, a regression to some unused resources" (1981/2014, p. 24). Anzieu describes two possible endings of the crisis - the successful completion of the crisis, thanks to which a new balance is achieved, with creative overcoming or finality, which implies the danger of serious decompensation, mental and somatic illness and even mental death, when regression finds only one empty mental space and resources for transformation are insufficient. From this point of view, the psychic work of 
creation, as well as the work of mourning, is directly related to the human existence, the struggle against non-existence, loss, separation, pain and ensuring the identification of a loved one and a lost object, which makes it live again (for example, in the form of characters from fiction literature or in the form of ideas, theories or concepts, in scientific work).

\section{The psychoanalytic portrait of the dictator}

Among the psychoanalysts who have analysed the dictatorial figures of the XXth century, I will refer to Eric Fromm. In his The Anatomy of Human Destructiveness (1973), Fromm formulates assumptions about the pathologies of Hitler and Stalin, the characters who have struck the minds of millions of people over a period of time and, certainly, committed their atrocities, demanding a revolutionary paradigm in the world. Fromm presents Stalin as an example of moral sadism, and Hitler particularly affects him as a case of psychic necrophilia, highlighting sadistic aspects and narcissistic pathology in his personality. Fromm mentions the properties of mental sadism such as the requirement of absolute control over another being, the requirement of omnipotence, the desire to overcome the limits of human existence, the inability to contain uncertainty, the desire to subdue people etc.

Fromm hypothesizes the predominance of Hitler's necrophilia traits and describes necrophilia in a characteristic sense as a passionate attraction to what is dead, to destruction, to the depredation of all living things, linking Hitler's necrophilia with a malignant incestuous character defined primarily by the inability to attach to the figures of parents: "It seems that such children never develop warm, erotic feelings for their mothers and never have any desire to be near them. Later they do not fall in love with their mother's substitutes" (1973/2015, p. 525). In this regard, Fromm argues that Hitler was completely deprived of warmth and incapable of human affection and that what many considered to be warmth and involvement, was actually the excitement that appeared when Hitler spoke of his favourite subjects or when he was in a vindictive and disruptive mood.

The analysis of Hitler's character shows that he was extremely narcissistic, isolated, uncontrollable, an extremely closed person for whom the fantasy was more real than reality. Wondering what traits allowed him to gain access to the soul of the masses, Fromm answered his ability to influence, impress and convince people, traits characteristic of all demagogues. In this sense, one of the factors related to Hitler's ability to impress was the unshakable trust in his ideas and the decisive speeches displayed firmly in front of an audience disillusioned and anxious by economic and social conditions. Moreover, another factor that contributed to Hitler's influence on the masses was his talent to simplify. Certainly, we can say that the 
categorical judgement of one's own ideas and the invitation to simplify reality is, in fact, an invitation not to think.

It seems that Hitler's outbursts of anger have been added to his perverse speech. His violent attacks, which could be very intense, appeared in his speeches, especially in conclusion, and contrasted with his general manner of behaving in a very elegant way. Fromm mentions that this anger was real because he was empowered by his most sincere passion for hatred and revenge, and believes that this very authenticity of his hatred made him so impressive.

It is important to note that Fromm mentioned Hitler's narcissistic pathology in his hypotheses and describes him as a narcissist, driven not only by the desire for power, but also by the need to ensure his mental health, which is a basic need of people with narcissistic pathology: “...they can try to change reality so that their great fantasies are real. This requires not only talent, but also favourable historical conditions. Most often, this solution is available to politicians in times of social crisis; if they have the talent to please the masses and if they are experienced enough to know how to organize them, they can bring reality into line with their dreams. Very often, the demagogue on this side of the border of psychosis maintains his mental health, making his ideas that seemed "crazy" until then, become "healthy" now" (1973/2015, p. 567).

The hypothesis of maintaining mental health on behalf of another person was also formulated by Paul-Claude Racamier (1987), when he presented the concept of narcissistic perversion. Racamier thinks that narcissistic perversion is dominated by the individual's need to assert himself on behalf of another person. "A narcissistic pervert has two vital imperatives: he must never depend on the object and he must never feel inferior" (2014, p. 126). The other will only be supported if its meaning is denied and it is dominated and mastered.

And, citing the way a narcissistic pervert maintains his mental health on behalf of others, Racamier mentions the pervert will try to protect himself from conflicting and deeply depressing areas of his own self through the following unconscious mechanisms: "first, avoidance of mourning by "extrusion" (that is, by exporting one's personal mourning, which has previously been disavowed and then distorted) on to someone else's shoulders: and, second, the perversive plugging of psychotic anxieties (a non-unusual vicissitude of the scars left by a psychosis as it heals)" (2014, p. 121). As for the impact of perverse thought on non-perverse thought, Racamier mentions that perverse thought is socially dangerous: "From deviousness to officialese, from verbiage to disinformation, from destabilization in families, groups and care 
institutions to the exercise of intellectual terror over nations, perverse thought is skilled in dividing but perfectly equipped to "swarm", and specializes in the transmission of non-thought" (2014, p. 130).

We can formulate the assumption that the dictator not only excludes the mourning of the other, but in general rejects it, suggesting that the other accept the maniacal mechanisms omnipotence and triumph. We see that the narcissisation of the dictator's ego is enormous and continuous in the context of narcissistic fragility, since the dictator is fully involved in selfinvestment on behalf of the masses.

\section{Masses mechanisms for the interaction with the dictator}

Let's see how the "cooperation" between the masses and the dictator takes place - both in terms of the dictator's idealization and ideology, as well as in terms of adherence to a specific procedure for identifying the enemy and involving the alleged enemy in the process of destruction.

As for the identification of the enemy, I will begin with Freud Totem and Taboo (1913), in which Freud refers to the origins of morality, guilt and religion, starting with the collective crimes of the brothers against their father in a primitive horde. Freud claims that in this oedipal conflict, our ancestors devoured their father, committing an initial crime that would condemn or honour a primitive man with the first rudiments of guilt. Freud's hypothesis is that the devoured father will be represented by a totem, a sacred object of the tribe that requires respect and godliness from all members of the community. Freud links the totem's constitution to guilt and fear of punishment arising from a crime committed against the tribe's father. From Freud's perspective, ambivalence characterizes the beginning of mental life both ontogenetically and phylogenetically. According to this perspective, both the individual and the community must work continuously on this mental reality. This conflict of ambivalence reaches everything power, status, prestige, authority, value, etc. And admiration for a representative of power or a person of value always implies envy and a desire to take the envied place. Freud suggests that our ancestors were ready to do the work to tame these trends in relation with authority, and one of the solutions found was to confer taboo status. Thus, a person brought up in society would be tabooed because "he is in a state that has the capacity to avoid forbidden passions, to cause a conflict of ambivalence. By their privileges, the king or ruler awakens envy. Everyone wants 
to, he could become king!" $(1913 / 2000$, c. 246). Freud seems to describe the psychic trajectory of neurotic evolution in this work, as a destructive act is followed by guilt and intent to repair. Now we know that the primitive part of Human does not always follow the neurotic path, and wars, social violence totalitarian regimes prove it.

According to Sigmund Freud, Melanie Klein continues this assumption about the role and power of envy at the beginning of mental life, noting that "envy is an extremely powerful factor in compromising the sense of love and gratitude at the root, as it affects the earliest relationships - the relationships with the mother" (1957/2006, p. 294). Melanie Klein argues that the main defence mechanism used in states of envy is the devaluation of the object. The depreciated object will not cause envy and the other will be constantly attacked, and this aggression is not caused by objective disorders coming from the other. Envy defines an attack on another, which is perceived as good, that is, in order to maintain the impression of omnipotence and self-idealization.

Paolo Fonda, in the article "The Mind at war" (2017), uses Klein's theory of schizoparanoid and depressive positions and considers that the evolution of group identity implies the existence of a non-differentiating state from which schizoparanoid and depressive positions are transformed. The depressive position is described by the ability to tolerate ambivalence, to feel love and care for others and to deal with the consequences of destructive attacks. Fonda claims that in times of social chaos, groups and communities return to a schizoparanoid position dominated by the projection of evil on others, the idealization of their own group, and the devaluation of another group. This regression to the schizoparanoid position also includes the logic of survival, including the protection of the regression group at an even more primitive stage - undifferentiated, when anxiety, panic, the group dissociate lose the identity. Fonda claims that schizoparanoid mechanisms prevail in times of war and social trauma, and in the last century they were the strongest in fascist and communist systems. In a schizoparanoid position, the one identified as the enemy is demonized and his human identity is revoked - he becomes like an object, dehumanized. This object will be the target of destructive attacks, and the appropriation of negative qualities and its dehumanization ensure the right and possibility of action to expose it to atrocities.

Thus, we conclude that the image of the enemy is captured in the mind of the phylogenetic and ontogenetic human and can be updated at critical moments in personal and collective history. In this sense, totalitarian systems and dictators resonate and collaborate with 
archaic human and social context. This reality also refers to the ability of a demagogue, dictator, repressive system to work with archaic material that is maintained to a certain extent in times of political, social, economic tranquility, when the law and framework are provided.

In Group Psychology and the Analysis of the Ego (1921) Freud is arguing with Le Bon, who has already formulated important ideas concerning the psychology of the masses, referring to the influence of the crowd on the thinking of the individual, the phenomenon of mental contagion the phenomenon of regression. Freud claims that the mind of the individual in the crowd has much in common with the psyche of a neurotic, a child or a primitive person. Feelings such as love and hatred are related to the functioning of the masses and characterize their relationship with the leader. Freud disagrees with the role attributed to the suggestion in communicating with the leader, and argues that a "love relationship" is what makes up the essence of the feelings that unite the masses. Freud analyzes two well-organized groups, the Church and the Army, in which love unites many people together, and each unites with the leader. But despite this love relationship, ambivalence exists from the very beginning, so that hostility is manifested through intolerance towards those outside the group:

"After all, any religion is a religion of love for those who embrace it, but each of them is immanent in its cruelty and intolerance towards those who do not accept it" (1921/2000, p. 70). Freud thinks that this intolerance persists in the socialist movement and predicts that socialism will show the same intolerance as in the religious struggle.

Freud also explores the similarities between mass psychology and the organization of a primitive horde. If all people in the Church or in the Army have the illusion that the leader loves them all equally and fairly, then on the contrary, in a primitive horde they are united by hatred, because "all children equally knew that they were persecuted by a father who inspired them all with one fear" (1921/2000, p. 88). In this sense, an analogy with the Stalinist repressive system and the Nazi system is required, where terror and fear existed even within the party (especially during the Stalinist period, terror within the party and manipulations with party colleagues were the determining reality of communication). It can be said that in totalitarian systems there is a regressive movement towards a specific operation of the "primitive horde".

In Group Psychology and the Analysis of the Ego, the identification is described as another important factor that can create an affective connection within the multitude. On this basis, Freud puts forward the following definition of the set having a leader, taking into account the role played by the Ideal Ego: "Such a primary mass is presented as the number of people to 
whom the Ideal Ego has been replaced by the same object. This was a consequence of the identification of their Ego" (1921/2000, p. 82).

Thus, we can say that in totalitarian systems the dictator identifies himself with the Ideal Ego, which belongs to the omnipotence of the Ego, and the crowd puts the dictator in the role of the Ideal Ego. The important role is also played by the Superego that is delegated to the dictator, who organizes deadly destructiveness, which also means that the crowd is no longer responsible, since they are delegated, for provoking their destructive drives.

\section{Conclusion}

The dictatorial system is built rather as a reality against a transforming creation, and as a reality by which the thought is annulated. This attempt at a totalitarian system of thought cancellation is supported by the peculiarity of the individual and the masses available for the non-thought. This accessibility builds on the various previous phases of our development and is related to the desire for regression, passivity, and a return to childhood, but also relates to the renewal of archaic experiences of envy, greed, anger etc.

Genius and creativity include mental work, through which a new libidinal transformational stage is achieved, beginning with the crises inherent to the human condition. Could be possible that a dictator is not able to perform this creative mental work. Emptiness, anxiety, powerlessness etc. - everything is solved through omnipotence, cancelling the reality and humanity. Thus, the dictator seduces the masses with this solution - in a simplified understanding of the human condition (including the splitting, projection, lack of relativity, simplification of the search for meaning, etc). Seduction is part of the dictator's arsenal of strategies, always followed, as Hannah Arendt (1964) explains, by intimidation and terror. This seduction comes through the promise to realize infantile desires and ideals that cannot be achieved. 


\section{REFERENCES}

ANZIEU, D. (1981). Psihanaliza travaliului creator [The Body of The Work]. Trei, Bucharest, 2004, pp. 23-25.

FREUD, S. (1921). Psihologia maselor și Analiza Eului. Studii despre societate și religie [Group Psychology and the Analysis of Ego.] Trei, Bucharest, 2000, pp. 49-107.

FREUD, S. (1913). Totem și tabu. Studii despre societate și religie [Totem and Taboo]. Trei, Bucharest, 2000, pp. 221-345.

RACAMIER, P.-C. (1987/2014). On narcissistic perversion. The Int J Psychoanal, 95 (1-2): pp. 119-132.

FROMM, E. (1973). Anatomia distructivității umane [The Anatomy of Human Destructiveness]. Trei, Bucharest, 2015, pp. 472-629.

ARENDT, H. (1964). Ce a rămas? A rămas limba. Convorbiri cu Günter Gaus. Ultimul interviu și alte convorbiri [What's remains? Language remains. Interview with Gunther Gauss. Last interview and other conversations]. Humanitas, Bucharest, 2018, pp. 5-41.

FONDA, P. (2017). A mind at war. Romanian Journal of Psychoanalysis, X (2): pp. 135-157.

KLEIN, M. (1946). Observații asupra unor mecanisme schizoid. Invidie și recunoștință [Notes on Some Schizoid Mechanisms. Envy and Gratitude]. Trei, Bucharest, pp. 15-54.

KLEIN, M. (1948). Despre teoria anxietății și vinovăției. Invidie și recunoștință. [On the Theory of Anxiety and Guilt. Envy and Gratitude]. Trei, Bucharest, pp. 54-82.

KLEIN M. (1957). Invidie și recunoștință. Invidie și recunoștință. [Envy and Gratitude]. Trei, Bucharest, pp. 294-390. 